OPEN ACCESS

Edited by: Qingxiang Meng, Hohai University, China

Reviewed by: Jie Zhu,

Ningbo University, China

Shuiping $L i$,

Yangzhou University, China

${ }^{*}$ Correspondence:

Jie Yang

zch198916@qq.com

Specialty section:

This article was submitted to Interdisciplinary Physics,

a section of the journal

Frontiers in Physics

Received: 24 September 2021

Accepted: 27 October 2021

Published: 12 November 2021

Citation:

Zhu C, Lou Y, Shen X, Xu H and Yang J (2021) Influence of CaO Content on the

Fly Ash-Lime System Hydrothermal

Synthesis Reaction Under

Autoclave Curing.

Front. Phys. 9:782309.

doi: 10.3389/fphy.2021.782309

\section{Influence of $\mathrm{CaO}$ Content on the Fly Ash-Lime System Hydrothermal Synthesis Reaction Under Autoclave Curing}

\author{
Chenhui Zhu ${ }^{1}$, Yilong Lou ${ }^{2}$, Xuemei Shen ${ }^{3}$, Hesi Xu ${ }^{1}$ and Jie Yang ${ }^{1 *}$ \\ ${ }^{1}$ School of Transportation and Civil Engineering, Nantong University, Nantong, China, ${ }^{2}$ Quzhou Water Resources and Soil and \\ Water Conservation Management Center, Quzhou, China, ${ }^{3}$ Water Project Management of Nantong-Lvsi Canal, Nantong, China
}

As a substitute for traditional Portland cement, the development and research of "lowtemperature-synthesized fly ash cement" has been receiving extensive attention. This study explores the effects of calcium oxide content on the fly ash-lime system hydrothermal synthesis reaction under autoclave curing, focusing on the effects of $\mathrm{CaO}$ content on the strength of the cement paste. The changes in phase composition, microstructure, and morphology were characterized using X-ray diffraction and scanning electron microscopy (SEM) analysis. The results show that with an increase in the $\mathrm{CaO}$ content, the amounts of $\beta-\mathrm{C}_{2} \mathrm{~S}$ and $\mathrm{C}_{12} \mathrm{~A}_{7}$ in the gelling material also increase. However, when the $\mathrm{CaO}$ content is very high, the amounts of $\beta-\mathrm{C}_{2} \mathrm{~S}$ and $\mathrm{C}_{12} \mathrm{~A}_{7}$ in the gelling material no longer increase, and the strength is lost.

Keywords: $\mathrm{CaO}$ content, low-temperature-synthesized fly ash cement, autoclave curing, micro-composition, morphology

\section{INTRODUCTION}

Cement is an indispensable building material in contemporary society. Its manufacturing process consumes a large amount of non-renewable resources as well as energy, which leads to greenhouse gas emissions [1-4]. Therefore, researchers have been extensively searching for an alternative gelling material.

High belite cement is one of the most researched alternatives. Three types of high belite cements have been studied, which includes: 1) belite-rich Portland cement [5-8];2) belite-rich sulfoaluminate cement or aluminoferrite cement as the main hydraulic minerals [9-17]; and 3) low-temperaturecalcined active belite cement or low-temperature-synthesized fly ash cement [18-21]. Lowtemperature-synthesized fly ash cement provides additional advantages of employing solid waste instead of clay as a resource. This decreases the consumption of limestone and allows sintering at low temperatures, which saves energy, and protects the environment. Therefore, it has good prospects for further development. Fly ash, lime, and a small number of admixture are smoothly mixed, and water is added until it molds. Subsequently, steam is cured at $100^{\circ} \mathrm{C}$ for $6-12 \mathrm{~h}$ to form calcium silicate hydrate and calcium aluminate. They are calcined at a proper temperature and heat is preserved until they quench. They are finely grounded and subsequently gypsum is added to finally produce cement.

This article prepared low-temperature-synthesized fly ash cement at different mixing ratios of $\mathrm{CaO}$ and $\mathrm{Na}_{2} \mathrm{O}$. The effects of changing atmospheric pressures were observed during autoclave curing. Additionally, we observed the effects of calcium oxide content on the fly ash-lime system hydrothermal synthesis reaction under the autoclave curing. Particularly, this article focused on the 
TABLE 1 | Chemical composition of fly ash.

\begin{tabular}{lcccccccccc}
\hline Composition & $\mathbf{C a O}$ & $\mathbf{S i O}_{\mathbf{2}}$ & $\mathbf{A l}_{\mathbf{2}} \mathbf{O}_{\mathbf{3}}$ & $\mathbf{F e}_{\mathbf{2}} \mathbf{O}_{\mathbf{3}}$ & $\mathbf{M g O}$ & $\mathbf{S O}_{\mathbf{3}}$ & $\mathbf{N a}_{\mathbf{2}} \mathbf{O}$ & $\mathbf{K}_{\mathbf{2}} \mathbf{O}$ & $\mathbf{T i O}_{\mathbf{2}}$ & $\mathbf{L O I}$ \\
\hline Content (\%) & 2.26 & 49.21 & 29.46 & 4.36 & 0.80 & 0.18 & 0.39 & 1.21 & 1.21 & 10.08
\end{tabular}

\begin{tabular}{|c|c|c|c|c|c|}
\hline \multirow[t]{2}{*}{ Specimens no } & \multicolumn{2}{|c|}{ Component } & \multicolumn{3}{|c|}{$\begin{array}{l}\text { Compressive } \\
\text { strength/MPa }\end{array}$} \\
\hline & $\mathrm{CaO}(\%)$ & $\mathrm{Na}_{2} \mathrm{O}(\%)$ & $3 d$ & $7 d$ & $28 d$ \\
\hline$A$ & 33 & 1 & 10.7 & 14.8 & 43.3 \\
\hline$B$ & 38 & 1 & 12.9 & 15.1 & 44.7 \\
\hline C & 42 & 1 & 17.1 & 21.8 & 50.1 \\
\hline $\mathrm{D}$ & 50 & 1 & 12.4 & 17.6 & 48.8 \\
\hline
\end{tabular}

effects of $\mathrm{CaO}$ content on the compressive strength of the prepared cement pastes. The changes in the phase composition, microstructure, and morphology were characterized using X-ray diffraction (XRD) and scanning electron microscopy (SEM) analyses.

\section{MATERIALS AND METHODS}

The fly ash in the test was a gray powder. The specific surface area of the raw fly ash was $257.9 \mathrm{~m}^{2} \mathrm{~kg}^{-1}$, the specific surface area of ground fly ash was $436.2 \mathrm{~m}^{2} \mathrm{~kg}^{-1}$, and its chemical composition is as shown in Table 1. We analyzed pure lime i.e., $\mathrm{CaO}$ in the tests.

The fly ash and lime were mixed smoothly at a certain percentage (the $\mathrm{CaO}$ content was 33, 38, 42\%and $50 \%$, respectively), and an appropriate amount of $\mathrm{NaOH}(1 \%$ measured by $\mathrm{Na}_{2} \mathrm{O}$ ) was added. The sample was homogenized by adding water at a water:material ratio of 1:1. Subsequently, the prepared specimen was placed in an autoclave $\left(\right.$ at $160^{\circ} \mathrm{C}$ for $8 \mathrm{~h}$ ), which was placed in a thermostat oil bath cauldron. The obtained autoclaved material was a synthetic material (precursor). It was calcined at $780^{\circ} \mathrm{C}$ in a high-temperature furnace and this temperature was maintained for $1.5 \mathrm{~h}$. Subsequently, the material was quenched in air to obtain clinkers. The obtained clinkers were ground to a particle size of $0.08 \mathrm{~mm}$ using a mill, leaving a residue of $2 \%$ on the sieve. The ground clinkers were mixed with lime to obtain the gelling material.

The gelling material was made into a cement paste, with a water-cement ratio of 0.5:1; it was poured into a $20 \times 20 \times 20 \mathrm{~mm}$ size model. This was placed undisturbed in wet air for $24 \mathrm{~h}$ and was later demolded. Subsequently, it was maintained in water at $20 \pm 1^{\circ} \mathrm{C}$. Additionally, the compressive strengths were tested at $3 \mathrm{~d}, 7 \mathrm{~d}$, and $28 \mathrm{~d}$.

\section{RESULTS AND ANALYSIS}

\section{Cement Paste Strengths}

The results are presented in Table 2. The compressive strengths of the cement pastes at $3 \mathrm{~d}, 7 \mathrm{~d}$, and $28 \mathrm{~d}$ were maximum when the
$\mathrm{CaO}$ content was $42 \%$. This was because when $\mathrm{CaO}$ was present in excessive amount, the content of dissociative $\mathrm{CaO}$ in the gelling material also increased and produced $\mathrm{Ca}(\mathrm{OH})_{2}$ on hydration, which further influenced (increased) the compressive strength of cement pastes. When the content of $\mathrm{CaO}$ was low, the content of $\mathrm{C}_{2} \mathrm{SH}_{2}$ and $\mathrm{C}_{3} \mathrm{AH}_{6}$ in steam curing decreased, which further decreased the amount of $\beta-C_{2} S$ and $C_{12} A_{7}$. This deteriorated the quality of gelling materials.

\section{Micro-analysis XRD Analysis}

This article conducted XRD analysis of the prepared specimens $\mathrm{B}$ and $\mathrm{C}$ (with $\mathrm{CaO}$ content 38 and $42 \%$, respectively). Figure 1A shows the XRD atlas of the autoclaved material. In addition to the characteristic peaks of unreacted mullite and quartz, the XRD atlas exhibited the presence of C-S-H(I), C-A-H, $\mathrm{C}_{3} \mathrm{ASH}_{4}, \mathrm{CH}$, and $\mathrm{CaCO}_{3}$ from the hydrothermal synthesis reaction and a small amount of reacted tobermorite in the autoclaved material. Figure 1B exhibits the XRD atlas of specimens B and C after calcination. In addition to the residual mullite and silica, the characteristic peaks of $\beta-\mathrm{C}_{2} \mathrm{~S}, \mathrm{C}_{12} \mathrm{~A}_{7}, \mathrm{CaCO}_{3}$, and some melilite calcium aluminum (non-gelatinous) were observed. Figure 1C shows the XRD atlas of the two specimens ( $\mathrm{B}$ and $\mathrm{C}$ ) in hardened cement pastes (28d) obtained from their corresponding gelling materials. As the $\mathrm{CaO}$ content increased, the $\mathrm{Ca}(\mathrm{OH})_{2}$ content (in the hydration sample) and the gelling material also increased. The diffraction peaks of $\mathrm{Ca}(\mathrm{OH})_{2}$ and gelling material were acute, and the strength of the diffraction peak increased.

From the XRD atlas, this article concluded that the $\mathrm{CaO}$ content, to some extent, influenced the phase composition and content of the autoclaved materials, calcined materials, and hardened cement pastes. With an increase in the content of $\mathrm{CaO}$, the hydrothermal synthesis in the autoclaved material increased, which further increased the content of $\mathrm{Ca}(\mathrm{OH})_{2}$. Therefore, the amounts of gelling materials in the calcined materials increased. Additionally, the content of dissociative $\mathrm{CaO}$ increased. When it approached $50 \%$, the increase in the gelling material was limited. The redundant unreacted $\mathrm{CaO}$ converted into dissociative $\mathrm{CaO}$ in the gelling material, which decreased the compressive strength.

\section{Morphologies Analysis}

\section{Morphologies of Autoclaved Materials}

Figures 2A,B shows the SEM analysis of the autoclaved materials of fly ash-lime system with different $\mathrm{CaO}$ contents after autoclaved curing at $160^{\circ} \mathrm{C}$ for $8 \mathrm{~h}$. The material exhibited in Figures $2 \mathrm{~A}, \mathbf{B}$ contain 42 and $50 \% \mathrm{CaO}$ respectively. When $\mathrm{CaO}$ doping was $42 \%$, the hydrothermal reaction produced a large number of gelatinous $\mathrm{C}-\mathrm{S}-\mathrm{H}$, other hydration products, some 


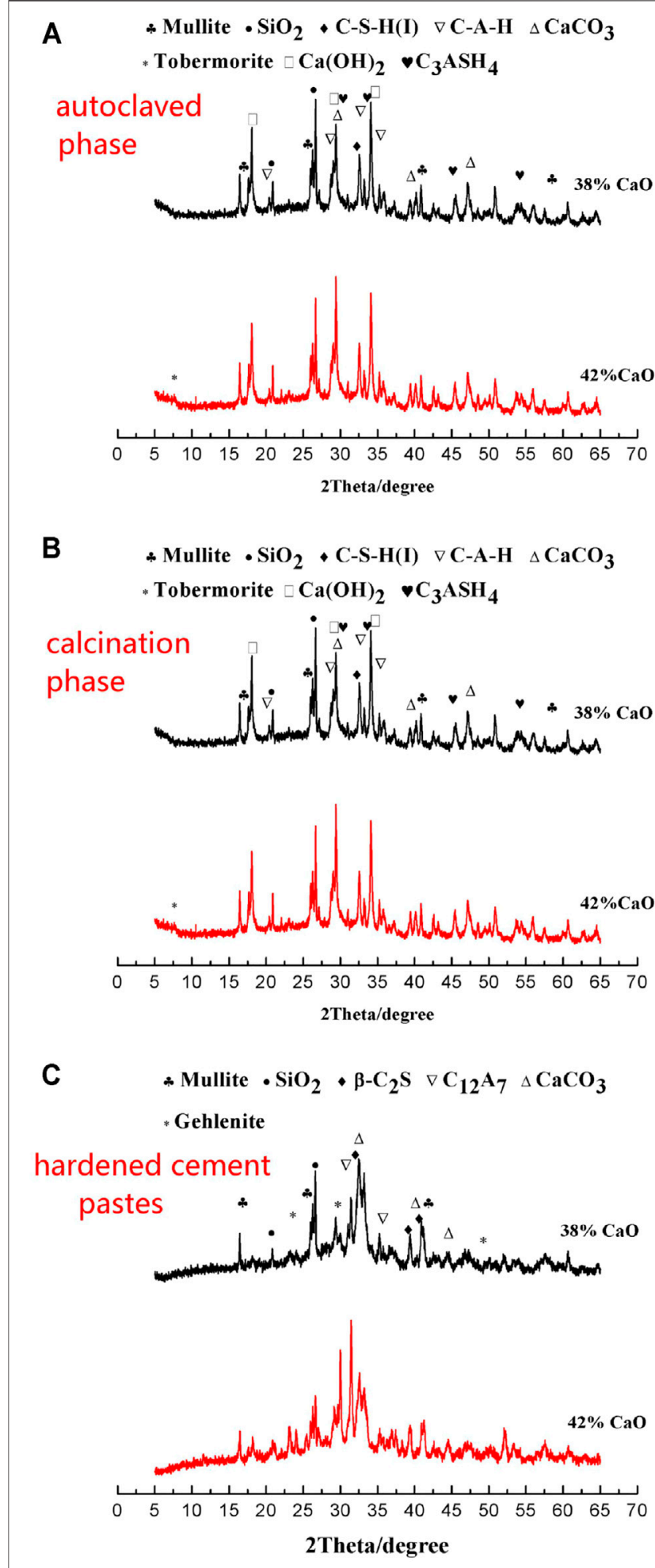

FIGURE 1 |X-ray diffraction patterns of the two specimens (B and C): (A) autoclaved, (B) after calcination, and (C) hardened cement pastes.

well-crystallized octagonal-shaped $\mathrm{C}_{3} \mathrm{ASH}_{4}$, and a small number of $\mathrm{Ca}(\mathrm{OH})_{2}$ crystals partially carbonized into $\mathrm{CaCO}_{3}$. Additionally, the surfaces of the particles exhibited a layer of hydration products with pores which overlapped each other. The well-crystallized tobermorite crystals formed using some gelatinous substances produced layered materials composed of single chain $\mathrm{Si}-\mathrm{O}$ tetrahedral and polyhedral $\mathrm{CaO}$. Figure 2 shows flaky or sheet like structures with their length varying from 4.5 to $11 \mu \mathrm{m}$. The fine particles of irregular mullite and quartz grains were wrapped with condensed matter and were not involved in the hydrothermal synthesis reactions. This micromorphology was consistent with the XRD results. From specimen $\mathrm{B}$, it was observed that when the $\mathrm{CaO}$ content was $50 \%$, the gelatinous material produced in the autoclaved material did not increase, whereas the crystalline state of $\mathrm{Ca}(\mathrm{OH})_{2}$ increased, and $\mathrm{CaO}$ did not participate in the reaction. $\mathrm{CaO}$ was present in the autoclaved materials, therefore the autoclaved material had greater amount of free $\mathrm{CaO}$. Additionally, the aggregation of the particles was loose, the pores were large, and the whole structure was relatively loose. This indicated that the amount of $\mathrm{CaO}$ in the ingredients was not too high.

\section{Morphologies Analysis of Calcined Materials}

Figures 2C,D shows the SEM analysis of the calcined fly ash-lime system with different $\mathrm{CaO}$ contents after hydrothermal synthesis and calcination at $780^{\circ} \mathrm{C}$. The $\mathrm{CaO}$ content in Figures 2C,D was 42 and 50\%. As observed from Figure 2C, before hydrothermal synthesis, C-S-H and C-A-H gels convert to $\beta-C_{2} S$ and $C_{12} A_{7}$, respectively under high temperature. The hydrothermally synthesized $\mathrm{C}-\mathrm{S}-\mathrm{H}$ was gelatinous; $\beta-C_{2} S$ also remained gelatinous but the $\beta-C_{2} S$ particles were finer than that of $\mathrm{C}-\mathrm{S}-\mathrm{H}$. The better crystallized $\mathrm{Ca}(\mathrm{OH})_{2}$ in the autoclaved material decomposed into $\mathrm{CaO}$ and some substances such as irregular mullite, quartz particles, and $\mathrm{CaCO}_{3}$ did not participate in the reaction of hydrothermal synthesis. It was observed that the calcined materials had higher porosity, lower crystallinity, looser structure, and higher activity, owing to the high porosities of $\beta-C_{2} S$ and $C_{12} A_{7}$. Some materials exhibited a long square columnar crosssection, which was designated as the non-gelling calc alumina feldspar crystal $\left(\mathrm{C}_{2} \mathrm{AS}\right)$, produced by the decomposition of $\mathrm{C}_{3} \mathrm{ASH}_{4}$. This micromorphology was consistent with the XRD results. Figure $2 \mathrm{D}$ indicated that when the $\mathrm{CaO}$ content was increased to $50 \%$, there was no increase in the content of $\beta-\mathrm{C}_{2} \mathrm{~S}$ particles. The amount of most important cementitious minerals did not increase, and therefore the final strength did not improve. Additionally, the strength decreased owing to the existence of too much free $\mathrm{CaO}$.

\section{Morphologies Analysis of $28 d$ Hardened Pastes}

Figures 3A,B exhibits the SEM analysis of the $28 \mathrm{~d}$ hardened cement pastes prepared using the fly ash-lime system with different $\mathrm{CaO}$ contents. The $\mathrm{CaO}$ doping in Figures 3A,B was 42 and $50 \%$, respectively. Figure $\mathbf{3 A}$ shows that after curing for 28 days, when the $\mathrm{CaO}$ content in the original mixture was $42 \%$, a large number of needle and flake hydration products were generated in the hardened cement slurry, including a well-crystallized flake or plate tobermorite composed of a 

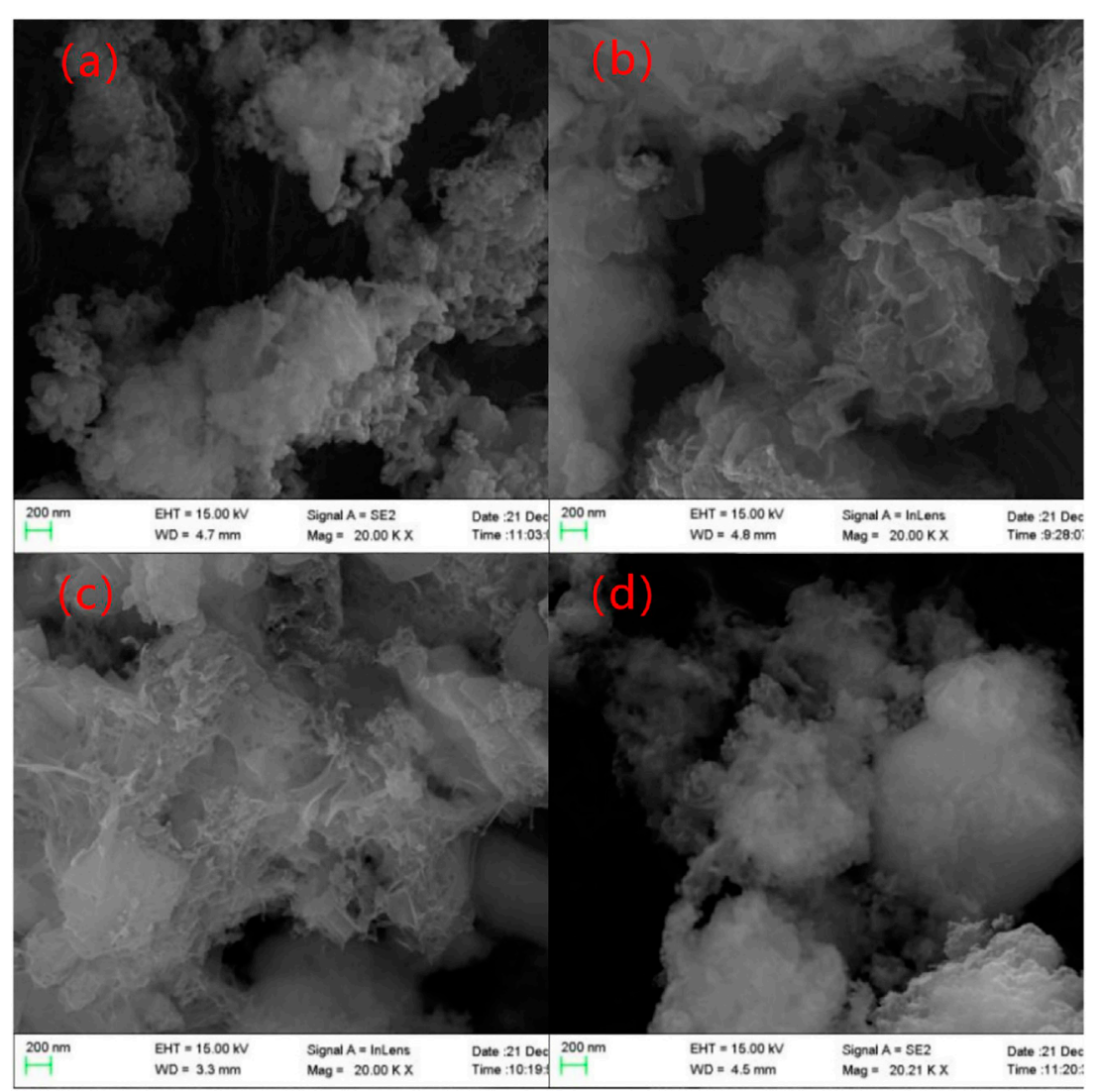

FIGURE 2 | SEM patterns of different autoclave (A and B) and calcining (C and D) materials.

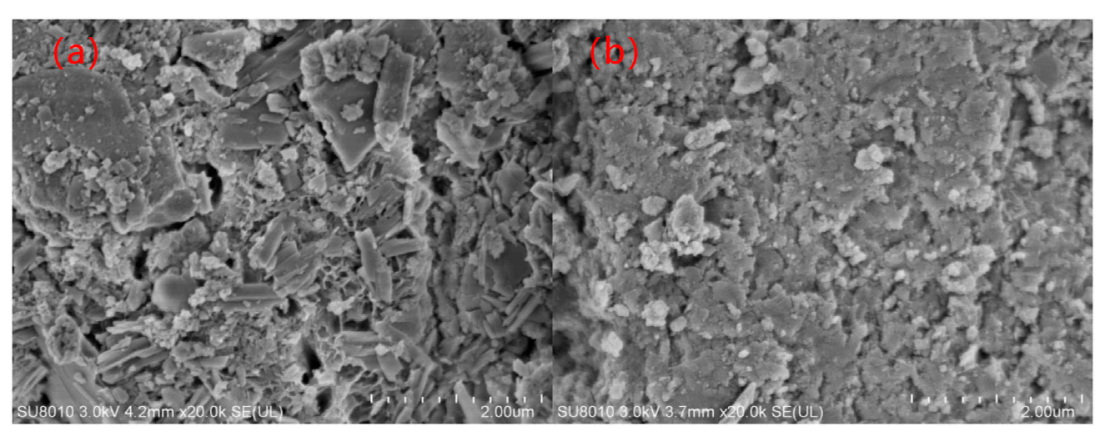

FIGURE 3 | SEM patterns of different hardened cement pastes.

single chain silica tetrahedron and $\mathrm{CaO}$ polyhedron. These were clustered with the generated $\mathrm{Ca}(\mathrm{OH})_{2}$ crystals and $\mathrm{CaCO}_{3}$, forming a network structure with a small number of pores. Almost all the $\mathrm{C}_{12} \mathrm{~A}_{7}$ particles hydrated rapidly at $28 \mathrm{~d}$, while a small amount of small $\beta-\mathrm{C}_{2} \mathrm{~S}$ particles present at the edge of the gel product were not hydrated. After adding gypsum, before molding, with the hydration at 28d, larger needles and sheet calcite crystals were observed, which mainly existed in some holes and seams. Owing to the decomposition of the hydrated garnet, some non-gelling calc alumina feldspar crystals $\left(\mathrm{C}_{2} \mathrm{AS}\right)$ were formed. The SEM analysis exhibited a long square columnar section, which was consistent with the results of XRD and exhibited a low 28d strength. Figure 3B, shows that on increasing the $\mathrm{CaO}$ doping to $50 \%$, the $\mathrm{CaO}$ required for hydrothermal synthesis reached a saturation state, and the resulting hydrated calcium silicate and other gel products were flocculent. Compared with that of the $\mathrm{CaO}$ doping of $42 \%$, the particles at $\mathrm{CaO}$ doping of $50 \%$ were loosely bound and resulted in a loose structure. Additionally at $\mathrm{CaO}$ doping of $50 \%$ there was more 
$\mathrm{Ca}(\mathrm{OH})_{2}$ crystallization, excess $\mathrm{CaO}$, irregular mullite, quartz, and other particles occupying the holes and structural gaps. Therefore, when high amount of $\mathrm{CaO}(50 \%)$ was doped into the original ingredients, the pressure strength of the produced cement hardener did not show any change (neither increased nor decreased). This indicated that when the amount of $\mathrm{CaO}$ doping exceeded $42 \%$, it had a negligible effect on the strength of the produced hardened cement slurry.

\section{CONCLUSION}

1) Under autoclaved conditions, the main gelatinizing active substance in the calcined material prepared by the hydrothermal synthesis of the fly ash-lime system was $\beta-\mathrm{C}_{2} \mathrm{~S}$ and $\mathrm{C}_{12} \mathrm{~A}_{7}$. With an increase in the $\mathrm{CaO}$ content, the amount of $\beta-C_{2} S$ and $C_{12} A_{7}$ in the final cementitious material increased correspondingly. When the content of $\mathrm{CaO}$ reached $50 \%$, the amount of $\beta-\mathrm{C}_{2} \mathrm{~S}$ and $\mathrm{C}_{12} \mathrm{~A}_{7}$ did not change significantly. However, the existence of excessive free $\mathrm{CaO}$ led to a loose structure and loss of strength.

2) The results showed that the compressive strength of the paste reached a maximum at $3 \mathrm{~d}, 7 \mathrm{~d}$, and $28 \mathrm{~d}$ when the $\mathrm{CaO}$ content was $42 \%$. When the $\mathrm{CaO}$ content was excessive, the content of free $\mathrm{CaO}$ in the cementitious

\section{REFERENCES}

1. Zhu B, Jiang D, Chen D, Li Q, Wang W. SFA-based Resource Consumption Analysis on China's Cement and Cement Based Materials Industry. J Tsinghua ci Technol (2014) 54(07):839-45. doi:10.16511/j.cnki.qhdxxb.2014.07.021

2. Zhu T, He W, Zeng X, Huang X, Ma BG. Environment Load from China' S Cement Production. Environ Sci (2006) 27(10):2135-8. doi:10.13227/ j.hjkx.2006.10.039

3. Liu Z, Guan D, Wei W, Davis SJ, Ciais P, Bai J, et al. Reduced Carbon Emission Estimates From Fossil Fuel Combustion And Cement Production In China[J]. Nature (2015) 524(7565):335-8. doi:10.1038/nature14677

4. Wang Y, Pan J, Pei R, Yang G, Yi B. A Framework for Assessing Green Capacity Utilization Considering CO2 Emissions in China-s High-Tech Manufacturing Industry[J]. Sustainability (2020) 12(11):4424. doi:10.3390/ su12114424

5. Chatterjee AK. High Belite Cements-Present Status and Future Technological Options: Part I. Cement Concrete Res (1996) 26(8):1213-25. doi:10.1016/00088846(96)00099-3

6. Fang Y, Cheng L, Gong Y, Yang W. Development and Future of Fly Ash Belite Cement[J]. J. Chinese Ceramic Soc. (2015) 43(2):165-73. doi:10.14062/ j.issn.0454-5648.2015.02.06

7. Kacimi L, Simon-Masseron A, Salem S, Ghomari A, Derriche Z. Synthesis of Belite Cement Clinker of High Hydraulic Reactivity. Cement Concrete Res (2009) 39(7):559-65. doi:10.1016/j.cemconres.2009.02.004

8. Chen Y-L, Lin C-J, Ko M-S, Lai Y-C, Chang JE. Characterization of Mortars from Belite-Rich Clinkers Produced from Inorganic Wastes. Cement and Concrete Composites (2011) 33(2):261-6. doi:10.1016/j.cemconcomp.2010.10.012

9. Goni S, Guerrero A, Lorenzo MP. Efficiency Of Fly Ash Belite Cement And Zeolite Matrices For Immobilizing Cesium[J]. J. Hazardous Mater. (2006) 137 (3):1608-617. doi:10.1016/j.jhazmat.2006.04.059

10. Glasser FP, Zhang L. High-performance Cement Matrices Based on Calcium Sulfoaluminate-Belite Compositions. Cement Concrete Res (2001) 31(12): 1881-6. doi:10.1016/s0008-8846(01)00649-4 material increased, and the $\mathrm{Ca}(\mathrm{OH})_{2}$ formed after hydration affected the strength of the paste. When the content of $\mathrm{CaO}$ was too low, the hydration products such as $\mathrm{C}_{2} \mathrm{SH}_{2}$ and $\mathrm{C} 3 \mathrm{AH} 6$ in the steam feed were reduced, which further reduced the production of $\beta-\mathrm{C}_{2} \mathrm{~S}$ and $\mathrm{C}_{12} \mathrm{~A}_{7}$ after calcination, leading to a decrease in the final cementitious properties.

\section{DATA AVAILABILITY STATEMENT}

The raw data supporting the conclusion of this article will be made available by the authors, without undue reservation.

\section{AUTHOR CONTRIBUTIONS}

$\mathrm{CZ}$, write $\mathrm{YL}$, provide materials XS, macro analysis HX, collating test results JY, analysis result.

\section{FUNDING}

This research was funded by the Nantong University College Students' innovation and entrepreneurship training program (Grant No. 202110304115Y).

11. Tong S, Kong X, Tian H, Wang D. Effects of Comb-like PCE and Linear Copolymers on Workability and Early Hydration of a Calcium Sulfoaluminate Belite Cement. Cement Concrete Res (2019) 123:105801. doi:10.1016/ j.cemconres.2019.105801

12. Yuuki Koga G, Paul C, Albert B, Roche V, Nogueira RP. Effect of Endogenous Chloride Contamination on the Electrochemical and Hydration Responses of Reinforced Belite-Ye'elimite-Ferrite (BYF) Cement Mortars. Cement Concrete Res (2019) 122:212-26. doi:10.1016/j.cemconres.2019.04.022

13. Huang Y, Qian J, Kang X, Yu J, Fan Y, Dang Y, et al. Belite-calcium Sulfoaluminate Cement Prepared with Phosphogypsum: Influence of P2O5 and $\mathrm{F}$ on the Clinker Formation and Cement Performances. Construction Building Mater (2019) 203:432-42. doi:10.1016/j.conbuildmat.2019.01.112

14. Lu L, Zhao P, Wang S, Chen Y. Effects of Calcium Carbide Residue and HighSilicon Limestone on Synthesis of Belite-Barium Calcium Sulphoaluminate Cement[J]. J Inorgan Organometal Polymers Mater (2011) 21(04):900-05. doi:10.1007/s10904-011-9560-0

15. Zhao PQ, Lu LC, Wang SD, Wang H. Influence of High-silicon Limestone on Mineral Structure and Performance of Belite-Barium Calcium Sulphoaluminate Clinker[J]. Adv Mater Res (2011) 168-170:460-65. doi:10.4028/www.scientific.net/ AMR.168-170.460

16. Beltagui H, Jen G, Whittaker M, Imbabi MS. The influence of variable gypsum and water content on the strength and hydration of a belite-calcium sulphoaluminate cement[J]. Adv Appl Ceramic (2017) 116(4):199-06. doi:10.1080/17436753.2017.1289722

17. Iacobescu RI, Pontikes Y, Koumpouri D, Angelopoulos GN. Synthesis, Characterization and Properties of Calcium Ferroaluminate Belite Cements Produced with Electric Arc Furnace Steel Slag as Raw Material. Cement and Concrete Composites (2013) 44:1-8. doi:10.1016/j.cemconcomp.2013.08.002

18. Yang N. Low Carbon Cement Production Composed by $\mathrm{C}_{2} \mathrm{~S}$. Cement Tech (2010)(4) 20-5. doi:10.19698/j.cnki.1001-6171.2010.04.002

19. Pimraksa K, Hanjitsuwan S, Chindaprasirt P. Synthesis of Belite Cement from lignite Fly Ash. Ceramics Int (2009) 35(6):2415-25. doi:10.1016/ j.ceramint.2009.02.006

20. Yang N. Progress in Study of $\beta-\mathrm{C}_{2} \mathrm{~S}$ by Hydrothermal Processing. J Building Mater (2011) 14(2):145-54. doi:10.3969/j.issn.1007-9629.2011.02.001 
21. Mahoutian M, Shao Y. Low Temperature Synthesis of Cement from Ladle Slag and Fly Ash. J Sustain Cement-Based Mater (2016) 5(4):247-58. doi:10.1080/ 21650373.2015.1047913

Conflict of Interest: The authors declare that the research was conducted in the absence of any commercial or financial relationships that could be construed as a potential conflict of interest.

Publisher's Note: All claims expressed in this article are solely those of the authors and do not necessarily represent those of their affiliated organizations, or those of the publisher, the editors and the reviewers. Any product that may be evaluated in this article, or claim that may be made by its manufacturer, is not guaranteed or endorsed by the publisher.

Copyright $\odot 2021 \mathrm{Zhu}$, Lou, Shen, Xu and Yang. This is an open-access article distributed under the terms of the Creative Commons Attribution License (CC BY). The use, distribution or reproduction in other forums is permitted, provided the original author(s) and the copyright owner(s) are credited and that the original publication in this journal is cited, in accordance with accepted academic practice. No use, distribution or reproduction is permitted which does not comply with these terms. 